\title{
Raising the achievement of young-beginner readers of French through strategy instruction
}

\section{Ernesto Macaro and Lynn Erler}

\begin{abstract}
This article reports on an intervention study of reading comprehension among youngbeginner learners of French as a foreign language (L2) in England. A number of factors are currently contributing to low achievement in reading among this population of learners. Although research into reading strategies is extensive, and there is some evidence of success in reading strategy instruction, very few studies have focused on beginner readers and there are no examples of longitudinal interventions such as this one. A sample of 62,11-12 year olds underwent a programme of reading strategy instruction lasting 14 months. Measures were taken of French reading comprehension, reading strategy use and attitudes towards French before and after the intervention and findings compared to a group of 54 students not receiving the intervention. Results suggest that strategy instruction improved comprehension of both simple and more elaborate texts, brought about changes in strategy use, and improved attitudes towards reading.
\end{abstract}

\section{Context and Rationale}

Modern language teaching and learning in secondary education in England ${ }^{1}$ is approaching a state of crisis. Fewer students are opting to continue with a language beyond compulsory education (age 16) and reports of disaffection recur (Brown and Fletcher 2002; Stables and Wikeley 1999; Williams, Burden and Lanvers 2002). The government has recently decreed that learners be allowed to give up the learning of any foreign language after the age of 14 . The UK-based Nuffield Languages enquiry (2000) ascribes students' lack of interest and motivation to a MFL curriculum which fails to equip learners with the foundation language skills. Evidence collected by the schools inspection service for England (Dobson 1998) suggests that beginner learners at the age of 11 in Year 7, the first year of secondary school, make rapid progress with foreign language learning in the first 6 months but that progress slows from then on, 
particularly during Years 8 and 9 with a parallel dip in motivation (Chambers 1993; Jones, Jones, Ruddock, Demetriou, and Downes 2001). Inspection evidence points particularly to problems with the skill of reading where students' "experience of written language is often limited to comprehending short texts which rarely extend beyond a few sentences" (Dobson 1998, p.6). Indeed reading in a second language (L2), our own experience as teachers and teacher educators suggests, is conceived in the beginner classroom as simply a tool for exposing learners to written vocabulary and short phrases already presented orally. There is a distinct lack of focus on reading skills (Grenfell 1992, 1995; Erler 2002). Williams and Burden (1999) argue that this situation could be remedied by teaching reading strategies.

This study was therefore conceived with the broad aims of investigating whether a different approach to the teaching of L2 reading, incorporating reading strategy instruction, could lead to accelerated development in that skill and to greater learner motivation. A longitudinal study was devised, to begin roughly half way through the first year of language learning and to extend into the second year. To our knowledge this longitudinal intervention study, with young-beginner learners of French in secondary school, is the first of its kind.

\section{Research on Learner Strategies}

There has been a considerable body of research on the strategies that learners deploy in order to learn or use a second language. General strategy use has been explored quantitatively, and specific skills such as reading, both quantitatively and qualitatively. This body of research is now too vast to catalogue here but for seminal works see: Naiman, Fröhlich, Stern and Todesco 1975; O’Malley and Chamot 1990; Oxford, 1990; Rubin 1975; Wenden and Rubin 1987. More recent reviews include: Chamot 2005; Cohen 1998; Macaro 2001, 2006; McDonough 1999; Oxford,1996;.

Critical observations have also been made of strategy research notably: (a) that definitions do not provide a distinction between mental activity and overt motor behaviour (Dörnyei and Skehan 2003; Stevick 1990); (b) that it is unclear what the scope or size of a strategy is and therefore its relationship with processes and skills remains undefined (McDonough 1995; Stevick 1990); (c) that large and general strategies inventories (such as the Strategy Inventory for Language Learning, SILL, Oxford, 1990) are not transferable across socio-cultural domains, (LoCastro 1994; 
1995); (d) that the relationship between strategy use and language learning success is not necessarily a causal one (Rees-Miller 1993); (e) that the claim, that simply using more strategies is a key to skill proficiency, can be challenged. Rather, it is the effective use of combinations of context-specific and task-specific strategies that promote learning (Chamot 2005; Cohen 1998; Graham 1997; Macaro 2001, 2006; Vann and Abraham 1990); (f) that teachers would be better off spending time on teaching the language rather than wasting time on strategy instruction (Kellerman 1991; Rees-Miller 1993).

In order to address at least some of the concerns above we took the following theoretical and methodological perspectives:

(1) The study would identify context-specific and task-specific combinations of reading strategies that might be used by young-beginner readers and measure how these combinations might change over time as a result of instruction, rather than measuring individual strategy increase using non context-specific instruments;

(2) We would reserve for the term "reading strategies" those directly related to cognitive processes, i.e. working memory's involvement in decoding, processing and retrieving information when reading, and the metacognitive regulation of those processes, i.e. planning, monitoring, evaluating, and making decisions. We would refer to learner behaviour that might involve a whole number of strategies and overt actions as "approaches to reading".

(3) The study would evaluate a longitudinal programme of reading strategy instruction which took up little teaching time but was designed to have a high impact on reading success.

Theoretical Background to Reading

Research on L2 reading has been extensive but has based itself on insights from first language (L1) reading models and research (Bernhardt 2000, 2005; Grabe and Stoller 2002). L1 reading research can generally be divided into two areas of interest, word recognition and whole-text access.

Research into word recognition in L1 reading emerged in connection with variability in processing times and in error rates and variation was applied to the study of cognitive processing impairment such as brain damage and dyslexias (Coltheart 
Patterson and Marshall 1980; Goswami and Bryant 1990). The same focus was adopted in L2 studies when researchers investigated different processing times and error rates across languages as well as whether different sound systems led to problems with word recognition (Feldman and Healy 1998; Koda 2000). Segalowitz, Poulsen and Komoda (1991, pp. 26-27) concluded from their study of French/English bilinguals that "the locus of L2 reading problems in skilled bilinguals is at the level of word recognition”. There was, during this period, general consensus that word recognition lay at the heart of reading comprehension (Laufer 1992; Nation 1990), the theory being that automaticity of word recognition frees up higher level processing for meaning across phrases, sentences, paragraphs and whole texts. Stanovich (1980) demonstrated, that poor (young) L1 readers had less automatic word recognition and needed to rely on context to recognise words. The implications for $\mathrm{L} 2$ reading were, therefore, that readers' inadequate knowledge of L2 lexis required alternative resources to access texts.

Considerations of these resources were supplied by the second area of interest in L1 reading, that of whole-text access. How could the meaning of a whole text be arrived at? Was it by bottom-up processes which involved decoding the text word by word and then clause by clause (La Berge and Samuels 1974), or was the reader dealing with the whole text as a unit, sampling words and strings of words, in order to predict, infer and confirm meaning in relation to an experiential conceptual framework which the reader supplied (Goodman 1967). Top-down processes implied that the reader would be elaborating the text in his/her mind and incorporating the meaning that was being extracted into their own knowledge and view of the world, their knowledge structures, their own schemata. The application of a distinction between top-down and bottom-up processes was easily transferred to L2 reading in that the L2 reader was more likely to encounter unknown words and might therefore resort even more to schemata-based inference.

Rumelhart (1977) and Stanovich (1980) pointed out the limitations of keeping these two areas of interest separate and Samuels and Kamil (1988) and Bernhardt (1991) proposed that each model was describing a different aspect of the overall process of reading. Thus models of reading both in L1 and L2 have recognised that combinations of top-down and bottom-up processes are involved in reading comprehension and that in fact what is being activated by a reader is an interaction between the two - hence the interactive model of reading (Carrell, Devine and Eskey 
1988). Although this model remained relatively stable over recent decades a number of very important questions remained unanswered: What exactly is the role of schemata in L2 reading?; what is the relative importance of each of the two sets of processes?; how, in fact, do the two processes interact? We will now examine each of these issues in a little more detail.

Schemata have been interpreted somewhat globally in the $\mathrm{L} 2$ reading literature. They have been interpreted both in a general sense, having knowledge of the topic of the text (for example, weddings in general) and specific or localized knowledge (American or Indian weddings, cf. Steffensen and Joag-Dev 1984). Additionally, these researchers have identified prior knowledge of the personal - the knowledge which only the reader has. Of course these three conceptualizations of prior knowledge are likely to interact during the processes involved in reading, creating misunderstandings of the text through false elaboration or distortions (Macaro, 2001). Despite this lack of precise definition of schemata, a number of studies have sought to investigate the extent to which prior knowledge of a topic renders the text easier to understand. Johnson (1982), for example, discovered that a lack of cultural familiarity with a topic could not easily be compensated for by focusing on vocabulary and other aspects of the surface text. Bügel and Buunk (1996) found that among 16 year olds, girls performed worse when tested on comprehension using texts which had boy-oriented topics and vice-versa. Hammadou (1991), on the other hand, found that students did not comprehend familiar topics better than unfamiliar ones and especially lower proficiency students were not able to compensate for lower language proficiency by being familiar with the topic. Parry (1993) found that cultural differences affected the extent to which prior knowledge was utilized by students, possibly the result of schooling traditions. In sum, the evidence as to the facilitating nature of prior knowledge is not conclusive.

A number of studies have sought to investigate the relative importance of topdown and bottom-up processing in reading comprehension. Carrell (1983) found in a series of experiments that her less successful L2 readers did not make use of cues that were available in a text and had little success in recalling a text. Chamot and El-dinary (1999) carried out case studies of 8 year old children in Canadian immersion programmes and found that low-achieving readers relied heavily on phonetic decoding and got bogged down by details. High-achieving readers used background knowledge (inference, prediction and elaboration strategies) and attempted to see the 
bigger picture. These findings would appear to give preference to top-down strategies. However, it is possible that higher-achieving students were better and faster decoders and therefore had no need to divert limited attentional resources to bottom-up processes. Moreover these authors found that high-achieving students frequently modified earlier predictions about the story as they acquired more information - again suggesting at least some focus on bottom-up processes. At least one L2 study, Nassaji and Geva (1999), has found efficiency in bottom-up processing to be the significant variable in students' reading comprehension results. However, Fukkink, Hulstijn and Simis (2005) found that, although they were able to train 14 year old Dutch students of L2 English to retrieve lexical items faster and with apparent greater automaticity, there was no transfer of these gains to reading speed of L2 texts, nor to higher-order reading comprehension.

These complex sub-processes have been investigated with a focus on monitoring of inference and comprehension. For example, Haynes (1984) found that university students experienced limited success when asked to guess words from global context clues but fared significantly better when guessing using local context clues. She concluded that learning to re-evaluate, via local information, an initial guess that had used global context, was as important as being encouraged to make the guess in the first place. Macaro (2001) found that among 14 year-old learners of French (English L1) the more successful readers made use of combinations of topdown and bottom-up processes, rarely sticking to one strategy within those processes for very long. In fact some of the less-successful readers overused prior knowledge leading to wild guesses about the content of the text. However, the interesting finding was that the prior knowledge strategy was used after the application of a bottom-up strategy: scanning for cognates. Unfortunately the cognates located in this fashion were not necessarily the keywords upon which prior knowledge could then be safely applied. McGowan and Turner (1994) similarly found that schema knowledge became an inhibitor rather than an aid to comprehension, that is, false assumptions being made which were not corroborated in the text.

As a result, a number of researchers now point to the importance of metacognition and self-regulation in applying the interactive model of reading appropriately. Metacognition, as a regulatory function in cognitive processing, has been identified in the field of psychology in general (Flavell 1979) and in the field of language learning in particular (Wenden 1999). By metacognition is meant the 
strategies involved in planning, monitoring and evaluating one's learning and/or one's strategy use. Block (1986), for example, was able to draw a distinction between two types of reader: the "integrator" reader who was aware of text structure by planning his/her reading, monitored understanding, read ahead in search for clues when they did not understand, evaluated their reading; and the "non-integrator" reader who relied on personal experiences to help them develop a version of the text. Graham (1997) records that more successful adolescent learners double-checked word and phrase meaning to make sure it made sense at word level and then at sentence and whole text levels. Anderson (1991), found that there was no single set of processing strategies that significantly contributed to success in reading but that a reader had to apply combinations of strategies in an orchestrated way.

In sum, the theoretical and research literature in L2 reading has taken L1 reading research as its starting point. This is not without its problems given the likelihood of a greater number of independent variables in L2 reading (e.g. L1, overall proficiency, age at which learning started, learning experience, attitude to the target language). The evidence suggests that, whilst prior knowledge is an important strategy to apply when reading, it can be misapplied. There is probably no hierarchy of top-down processes over bottom-up processes in more successful readers. The balance between the two needs to be arrived at through a metacognitive evaluation of the match between a number of variables including task requirements, text difficulty, and the learners' own L2 lexical knowledge. The selection of strategies to support this "balance of processes" needs to be orchestrated and monitored, via metacognition, for its effectiveness while reading.

Research into Reading Strategy Instruction

A number of researchers have looked to reading strategy instruction as a means of improving the use of strategies that support the interactive model of reading. However, most studies have involved adults or university students, not young learners.

There has been considerable interest in instructing learners to think about text structure (e.g. semantic mapping) with some encouraging results on comprehension success. Carrell, Pharis and Liberto (1989), Raymond (1993), and Talbot (1995) all 
found some benefit of instruction in these types of strategies on university level students, in different cultural contexts, and studying different languages. Kusiak (2001) also reports improved comprehension and attitudes to reading with Polish secondary school learners of English through instruction consisting of finding the main idea of a paragraph, recognising topic sentences, distinguishing main idea from supporting details, distinguishing different text patterns, concentrating on key words and guessing meaning from context. However, these studies had a number of limitations. In the Carell et. al. study, improved performance was observed on an open-ended question task but not on a multiple choice task which included inferencing questions, the same teacher taught both the experimental and control group and the sample was small $(\mathrm{N}=26)$. Additionally, a strategy-related task (partial semantic mapping) was attached to the tests which may have favoured the intervention group. Raymond's study reports positive results for one reading text but not for another whilst Talbot's study reports positive results in only 3 out of 4 components of the text. In none of these studies was there a systematic measurement of differences in strategic behaviour prior to and after the intervention to support the findings and, although Kusiak's intervention was considerable (eight 45 minute sessions), it was additional to the students' normal language study, possibly biasing the experimental group.

Fewer studies have concentrated on instructing students about strategies at the word or sentence level. Fraser (1999) identified two types of inferencing strategies: word-identification strategies which rely on the form/sound of the word to make informed guesses as to meaning, and sense-creation strategies which utilize both language and situational clues. In her study involving eight university students (French L1, English L2) she found that instruction in a range of lexical processing strategies was beneficial in terms of understanding text. Changes in strategy use were assessed via interview and supported the findings. Kitajima (1997) examined whether training in a strategy specific to Japanese (monitoring co-referents inter-sententially) could help American college students comprehend a Japanese text more successfully, i.e. a grammar awareness strategy. The experimental group outperformed the comparison group on 3 out of the 4 paragraphs on general comprehension and on two out of the 4 paragraphs on identifying the referents. However, again the sample was fairly small $(\mathrm{N}=28)$, sample selection methods had acknowledged limitations, and 
there was no measurement of strategy use after the intervention to triangulate the findings.

Maxim's (2002) study had some similarities with the current one even though it was with university students. He gave 27 beginner students additional reading in the form of a German novel after only four weeks of the course and compared the intervention group with a comparison group that was exposed to more traditional textbook reading. It is unclear exactly what the strategy training consisted of and how explicit the range of strategies offered to the students. At post-test there were no significant differences in reading comprehension scores between the two groups but the treatment group showed a significant increase in its ability to read faster while not demonstrating any decline in any of the other language skills. Maxim concludes that a course with a strong reading-based focus can be introduced to students sooner than it is thought.

Thus, interventions focusing on reading strategies have provided some positive results with older learners and learners at intermediate or advanced levels of proficiency. These interventions have concerned themselves with the comprehension of texts of some considerable length. At these levels, and with these text-types, the strategy instruction has tended to be concerned with text structure rather than the relative importance of top-down or bottom-up strategies. Nevertheless, it appears that strategy instruction may prove beneficial and it might be worth giving up language exposure time to carry it out. There are, however, some methodological issues of which perhaps the most important is whether the change in strategy use has been measured or whether its relationship with comprehension outcomes simply assumed. Additionally, sample sizes have tended to be small and few studies report in detail the nature and extent of the strategy instruction as a proportion of normal teaching. There have been few attempts to control for the teacher as a variable and no studies describe how learners received feedback regarding their on-going strategy use, as is the case in the current study. The need for rigorous interventions studies which include schoolaged students in the foreign language context has also been highlighted by Chamot (2005) in her review of strategy instruction research in general. Finally we conclude from the review that there have been virtually no studies of reading French as a foreign language with young-beginners and that no longitudinal studies of the effectiveness of reading strategy training have been carried out. Indeed, there is perhaps more to be gained in our study by comparisons with L1 research among low- 
achieving readers (e.g. Brown, Pressley, Van Meter, and Schuder 1996) where successful strategy instruction has resulted from text-engagement strategies with high levels of teacher scaffolding.

These factors influenced both our research questions and our methodology.

Research Questions

1. Can a programme of reading strategy instruction provide young-beginners with the means to understand French texts better?

2. Can a programme of reading strategy instruction bring about change in strategies for and approaches to reading, that is, in the combinations of strategies used?

3. How do students react to a programme of strategy instruction in terms of their attitudes toward reading in French?

Method

Study Type

The study was a quasi-experimental researcher-manipulated evaluation involving a pre- and post-test design with a sample of six matched intact classes of Year 7 and Year 8 (age 11-13) students in secondary schools in England. The classes were not randomized because of a number of educational constraints. Firstly, the study was a longitudinal one spanning 15 months. In England classes at this age level, which stay intact for this length of time, are in the minority. This restricted the researchers in their sampling procedure. Secondly, the study was designed to begin after four months of L2 instruction and it would have been difficult to convince school principals to randomly allocate at that stage individual students to different conditions. Thirdly, the six classes were matched rather than randomly allocated 
because of resource constraints - the intervention schools were close to the university where the researchers worked, the comparison schools were located some distance away to avoid possible contamination in an educational environment where local teachers meet quite often.

\section{Population and Sample}

The study investigated a population of beginner learners of French as a Foreign Language in English state comprehensive ${ }^{2}$ schools. This population is characterized by a number of features some of which have already been described in the background section. The population's first language is, overwhelmingly, English, although a considerable minority of non-English first language can be found in large cities such as London and Birmingham. Due to resource limitations, our sampling frame was schools in four different education authorities in southern England which did not include large urban populations. To that extent the frame does not fully represent the population.

Six schools were invited and accepted to take part in the project. Six teachers, one each per school, agreed to participate with their Year 7 class. Again, therefore, some caution has to be exercised as to the representativeness of the sample. The project intervention cohort comprised three teaching groups in three of the schools and the comparison cohort comprised three teaching groups in the other three schools. Attempts were made to match the two cohorts as closely as possible (see Appendix A). Additionally the experience levels of the teachers were matched. In each cohort, two "experienced teachers" had taught more than ten years and one "novice" had less than three years of teaching experience.

At the start of the project (January, henceforth Time 1), all the students had been learning French in secondary school since September, representing approximately 38 hours of classroom teaching time. Four different textbooks, all devised in response to the National Curriculum for Modern Foreign Languages (DFEE, 1995) were in use by the various groups.

Consent was sought and obtained from students and their parents/guardians for participation in the research project. The initial sample consisted of 166 eleven to twelve year olds. The mean age at the start of the research was almost 11 years 5 months $(11.48)(\mathrm{SD}=.47)$. There were 77 boys $(46.4 \%)$ and 89 girls $(53.6 \%)$. 
Students in the comparison cohort were told that the researchers were interested in their approaches to reading over a period of time and how well they could understand a text in French. All aspects of the intervention were made transparent to the intervention cohort.

By the end of the project (March of the following year, henceforth Time 2), 15 months after the pre-tests, five of the six classes had remained intact with the odd addition or loss of students. One comparison class was unexpectedly rearranged, by the school management, halfway through the second year resulting in the loss of half its original students. Additional differences between original sample and final sample were due to absences at post-testing. Thus $69.8 \%(\mathrm{~N}=116)$ of the initial sample filled in the questionnaires and attempted all of the pre- and post-reading tests (see Table 1). Analysis showed that participant loss was random and therefore not statistically relevant to analyses carried out on the data. In other words, the participants and non participants at Time 2 did not differ in the reading tests at Time $1(p>.05)$.

\section{Research Instruments}

There were 4 research instruments for pre- and post intervention measurements:

(1) Two tests of reading comprehension in French;

(2) A questionnaire eliciting learners' strategies and general approaches to reading French text;

(3) A brief questionnaire eliciting learners' attitudes to reading in French.

The Reading Tests

No national standardized French reading tests were available at this level. The researchers therefore had to devise their own reading tests to answer research question 1. These comprised two types of reading texts and tasks (see Appendix B) which measured comprehension at two levels. Two texts (one at each time point) involved a "narrow reading" event (Krashen 2004; Parry 1993) requiring what amounted to a translation of the French text into English. Translation is considered to be a reliable method for measuring accurate understanding (Alderson 2000) and we refer to it as 
"translation" henceforth. The other two texts (one at each time point) measured broader reading comprehension as demonstrated by the number of idea units (Jacobs, Dufong and Hong 1994) which the learner reported. These two test types demanded different knowledge bases and strategy deployment, the one more bottom-up lexical and syntactical knowledge and the other greater orchestration of both top-down and bottom-up strategies.

At Time 1 the "translation" text consisted of 43 words and presented vocabulary and grammar levels consistent with the learners' current production tasks, confirmed by Year 7 teachers, the curriculum and the textbooks. At Time 2 the "translation" text consisted of 82 words and was again consistent with the learners' current production tasks and was confirmed by the teachers and the textbooks being used. To avoid a ceiling effect in the Time 2 test, due to progression the one-year time lapse between pre- and post-testing, the Time 2 "translation" test consisted of the original Time 1 "translation" text expanded by $30 \%$. It was expanded by adding a section that incorporated additional topic areas which all groups had covered since the pre-test including the past tense with which all groups had had at least some contact.

The grammar and vocabulary of Time 1 "idea units" text (86 words) was consistent with but also somewhat above the learners' current production level. The task requirement was to report in English the propositions which could be found in the text. The students could write down what these propositions were at any time during the task and they always had the text available to them. Following piloting, the concept of "idea units" (or propositions) was described to the students as looking for "main ideas", these being anything that they had understood in the text without necessarily focusing on individual words - hence the instructions provided (see Appendix B) relating to writing whole sentences rather than one or two words. At Time 2 a new "idea units" text was developed (204 words), which was based on a current world event (the Iraq conflict) and was designed to be considerably above not only the level of current production tasks but also above the level of what Year 8 learners would be given as reading material. This text nevertheless included schema clues, a short glossary and cognates, all designed to assist comprehension of the text via strategy use.

All tests went through a two-staged piloting process with students of the same age and mixed-proficiency levels of French as the study sample at Times 1 and 2 but in different secondary schools. The researchers invited pilot students' comments on 
whether they had understood the instructions and could, to some extent, understand the texts. As expected, pilot students at Time 2 proficiency found the Idea Units Time 2 text difficult.

The Strategies and Approaches to Reading Questionnaire

The questionnaire for reading strategies and approaches to reading (research question 2) had been used successfully by Erler (2002) as part of an exploratory descriptive account of Year 7 learners' experiences with reading in French. The development of that questionnaire followed extensive piloting with Year 7 students. It therefore resulted from a "grounded approach" to instrument development, and was developed entirely within the context of institution type and age/proficiency level. Additionally, it was shorter and felt to be more appropriate than questionnaires aimed at older adolescents and adults (e.g. the SILL, Oxford 1990). In Erler's (2002) questionnaire the strategies and approaches to reading were worded so as to be understood by Year 7 learners using the language that they had used to describe what they did. The list of reading strategies was, nevertheless, compared to reading strategy lists found in Chamot and Keatley ( 2003, cited in Chamot 2005), Oxford (1990), O’Malley and Chamot (1990), Graham (1997), and Macaro (2001), and demonstrated an acceptable range and completeness although by no means all possible reading strategies. For example, an approach such as "read and re-read" (as one reviewer suggested) was not included because none of the exploratory study data collected suggested that this was something Year 7 students did or were asked to do. The majority of tasks described by the students were of the "scan and match" type, for example scanning a short text for a word or phrase which matched a picture. We wanted to present the students with a questionnaire which matched the reality of their context. This independent development of a scenario-based strategy self-report questionnaire accorded to the recent call by researchers in the field for task-based strategy questionnaires (e.g. Ikeda and Takeuchi, 2000; Oxford, Cho, Leung and Kim, 2004; Wenden, 1995).

For the present study slight modifications were made to Erler's (2002) questionnaire, and the new version with twelve strategies/approaches, in random order, was again piloted with a group of Year 7 students who found it understandable, comprehensive and appropriate for their age group. This questionnaire (see appendix 
C) appeared to satisfy the students that it could report reliably on strategy use and on approaches to reading as perceived and reported by the student respondents. Respondents were given a choice of "yes", "no", and "sometimes" to items on strategy use or approach taken. Again, this was felt to be more appropriate than a 5point Likert scale for this age group. Cronbach alpha analyses yielded reliability coefficients for the total scale of .74 at Time $1(\mathrm{~N}=135)$ and .73 at Time $2(\mathrm{~N}=116)$. The questionnaire contained a mix of reading-related cognitive strategies and more general approaches which began with the lead question "When you see a French text of several sentences or a paragraph, do you...". As a result of the interviewing in Erler (2002) and piloting in the current study, the individual items can be interpreted as follows:

(1) Wait for the teacher to explain the text. A general approach to reading which does not engage independently with the text. There is a reliance on the teacher to "go through the text" with the class at some point.

(2) Skip it. A general approach when confronted with a text avoiding engagement, perhaps regarding it as an unnecessary or impossible task and may be linked to (1). They either did not do the task attached to the text, or they addressed the task by guessing, copying answers from other students, or waiting until the teacher put the answers on the board.

(3) Try to understand each word. A cognitive strategy in which there is full engagement with the text. However, this strategy may be over-used if time limitations, text length, or task demands operate against it.

(4) Go back to a word or section and double-check that it makes sense. A monitoring strategy based on information understood later in the text. Demonstrates high level of engagement with the text.

(5) Scan for words that look familiar and try to guess the meaning of the text from them. An inferencing strategy, using prior knowledge of the topic and known words to fill in the gaps or overcome obstacles to comprehension.

(6) Scan for words that look like English and try to guess the meaning of the text from them. Again an inferencing strategy similar to the one above. However, 
previous research with this age group (Macaro 2001, see above) found this strategy counter-productive if used in isolation.

(7) Guess from the pictures what it's all about. An inferencing strategy that could be over-applied and misused if used in isolation. Indeed, it could be considered to be, in some cases, a text-avoidance strategy.

(8) Invent a meaning. A general approach described by the piloting students in terms of text avoidance; merely to complete the task for the teacher. Students reported that the approach could refer to any amount of text, from a few words in an "advert" to a paragraph. The approach did not necessarily involve an appropriate or a logical inference. May be linked to (1).

(9) Ask a friend what it means. A general approach which has more to do with reliance on someone who might be of higher proficiency than some kind of positive "collaboration on a task". It should be remembered that these classes were largely mixed proficiency classes. Again "it" could refer to any amount of text from single word to whole text. We need to bear in mind that they rarely received text of more than a few sentences, as explained in the introduction and as is evidenced from their textbooks.

(10) Ask the teacher what it means. A general approach which suggests teacher reliance rather than self-reliance. Again "it" referred to any amount of text.

(11) Wait and see if the teacher says what it means. A general approach which differs slightly from (1) in that students described it more as referring to on-task explanation of difficult items rather than post-task "going through" of the whole text. Nevertheless a Pearson's product moment correlation showed a medium strength relationship between the two items at a significant level $(r=.5, p<.01)$.

(12) Look up many words in the dictionary or glossary. This can be interpreted as a general approach engaging with text which may, once again, be over-used without some metacognitive evaluation of task/text demands.

The Students' Attitudes to Reading 
Learners' attitudes to reading (research question 3) were elicited pre- and postintervention by a second section in the questionnaire (Appendix D), developed to track any change over time and in possible correlation to intervention results. Smiley faces (Mortimer, Sammons, Stoll, Lewis and Ecob, 1988) supported by text descriptors represented a Likert scale of one to five to indicate the respondent's attitude towards reading, the other three language skills, learning French (in general), French homework and the French textbook. During piloting respondents considered this questionnaire acceptable and adequate for expressing their attitudes. Cronbach alpha reliability coefficients for the attitudes section of the questionnaire were .70 at Time 1 and .86 at Time 2.

\section{Data collection}

The Time 1 tests and questionnaires were administered, by one of the researchers, in the respective classrooms during normal lessons in the Spring Term of 2003. Students were allowed to ask clarification questions and the concept of "main ideas" was carefully explained to all participants by the researcher. Fifteen months later (one month after the end of the strategy instruction) the Time 2 questionnaires and reading tests were administered by the same researcher in the same circumstances: at the beginning of a normal French class session with the same instructions for all groups. No assistance was given to the students for the tests and the class teacher was present but did not interact with the students during the questionnaire and tests. Time of day varied according to the lesson which was made available by the teacher. Time limits for the reading tests were kept constant. For the reading strategies questionnaire it was explained to the students that the questions related to any reading they did in French. Our knowledge of the classes, however, suggests that they rarely did reading comprehension exercises outside the classroom and certainly no extra-curricular reading.

The Strategy Instruction Programme 
The intervention spanned parts of two consecutive academic years consisting of staged strategy instruction based on the cycle proposed by Macaro (2001). Briefly, it was a programme which began with awareness raising and modelling of strategies, followed by scaffolded practice, by removal of scaffolding, and then by evaluation of attitudes toward reading.

In the first stage, strategies which learners already used were elicited from them and discussed. New strategies, or refinements on previous strategies, which could be used were introduced, and the effectiveness of various strategies was discussed. Additional strategies introduced were:

1. Guess from words around problem word

2. Think hard about words I might know (i.e. don't give up easily)

3. Use a process of deduction ("it can't be that because.....")

4. Sound out the word or phrase

5. Use common sense (prior knowledge)

6. Remember to read the whole sentence to see if it makes sense

Implicit in all these activities was the concurrent development of metacognition with regard to making decisions about clusters of strategies available, and evaluating strategies used. Awareness raising and modelling were also carried out through:

1. class discussions of the results from the pre-intervention strategy questionnaire;

2. a 4-part English story text with cloze-like exercises where the reader was challenged to infer an English meaning for French words and phrases which were scattered throughout the English text. The learner was asked to report which strategies he/she used to decide the English meanings for the French by using a strategies tick list. These tasks were followed by personalised written feedback to the learner on his/her success with inferencing and on their use of strategies in general;

3. encouraging students to attempt to decode words that were unfamiliar to them via sounding out the written word. In order to help them to do this, students were given "sound games" and a specially written song aimed at helping them remember some of the sounds of French. 
4. two "guided reading" texts where the students were reminded of all the strategies available for approaching a text: title, pictures, layout, and, in addition, all the strategies referred to above. Learners were encouraged to underline the language they knew, circle the language they did not know and to infer the meaning based on what they did know. Personalised feedback was again given.

The second stage was the scaffolded practice of old and new strategies. The principal scaffolding devices were the strategies tick list which elicited the learner's strategy use for the particular text and also reminded him/her of other strategies which could be used, and the personalised feedback on students' work (see examples in Appendix E). Teachers were encouraged to have students share and discuss their strategy use. Teachers also reminded learners of strategies during normal classroom work with written French. This stage further developed metacognition involving the awareness of one's own knowledge, of reading processes and the construction of meaning in relation to strategy use. The orchestration of a cluster of strategies thus demanded a continuous metacognitive decision-making process which included monitoring, evaluating and re-configuring the clusters of strategies used.

The third stage was the evaluation of strategy use. This was particularly supported by the personalised feedback, and by pair and class discussions. For example, students were encouraged to look at their personalized feedback, look back at the text they had attempted and consider what they might do when confronted with a difficult text in future. They were encouraged to discuss this with a partner. Another example was where a difficult text (in addition to the whole text in front of them) was cut up into strips of phrases. In groups, the children had to decide whether to put it in "know the meaning" or a "don't know the meaning" box. They were then encouraged to discuss which strategies they might best use to guess at the meaning of the unknown words or phrases. Thus, evaluation was not a stage carried out only at the end of the intervention but was on-going and integral to the instruction.

We describe the strategy training programme for this study as "low input, high scaffolding" for the following reasons. It was low-input because it was agreed that it would only take an average of 10 minutes per week from normal class time. Teachers generally preferred to block these 10 minute periods into longer units every two or three weeks. This meant that, after the strategy awareness phase, only 5 extra texts 
were provided over the next two terms. It was a high-scaffolding programme because with every text the researchers provided the list of strategies which learners were encouraged to try out in combinationand to tick them if they had used them. They were also asked to report any other strategies they had used. They received feedback not only on their strategy use but also on how that use might relate to their performance in the reading comprehension.

The strategy instruction programme texts were devised by the researchers in consultation with intervention teachers. All training materials were given to the teachers with instructions on how to present them to their classes. It was left to the teachers to decide when they used the materials. Periodic meetings were held by the researchers with the intervention teachers to review and clarify the stages of the cycle, to discuss the materials and the intervention teaching.

Comparison groups did not receive any input. They were not given the additional texts because without teacher intervention to help students to understand the texts the students would have found them challenging to the extent of possibly causing anxiety, thus undermining the reliability of the quasi-experiment.

Analysis

For the "translation" texts the researchers examined the two texts beforehand to establish a maximum number of textual units of meaning, a single content word or phrase, each unit corresponding to a point. For students to score a point their translation would have to match the word or phrase. The "translation" Time 1 text was scored on a maximum of 14 points. Expanded "translation" Time 2 text was scored on a maximum of 34 points. The "idea units" texts were parsed for ideas contained in them. In other words students could gain a point if they conveyed the propositions in the text even though they did not use direct translations of the words of the original. Time 1 text was established as having a maximum of 20 idea units. The "idea units" Time 2 text was allocated a maximum of 30 points. Interrater reliability was provided for by separate blind marking of $10 \%$ of each of the four tests by the two researchers. Correlations (Pearson's) obtained between the two researchers were: Time 1 "translation" $r=.948$; Time 1 "idea units", $r=.930$; Time 2 “translation", $r=.960$; Time 2 "idea units", $r=.817$. All correlations were significant 
$(p<.01)$. Disagreements were resolved via discussion. All raw scores for the tests were then converted to percentage proportions.

The questionnaire data on strategies and general approaches to reading were trichotomic ("yes", "no", "sometimes") and therefore not interrated. The attitudes questionnaire used Likert scales $(1=$ very unhappy, to $5=$ very happy $)$ and therefore was not interrated.

The reading comprehension tests were analyzed using non-parametric tests, following a Kolmogorov-Smirnov test of normality which showed that all four tests had a non-normal distribution $(p=.05)$. For the reading tests the $\mathrm{p}$-level for significance was set at .05 for Time 1 and at a more rigorous .01 for Time 2 because of the quasi-experimental and longitudinal nature of the study.

Results

Research Question 1

The first research question was concerned with whether strategy training in reading would result in better reading comprehension. Descriptive statistics are provided in Table 1 for "translation" tests, and for "idea units" tests.

INSERT TABLE 1 ABOUT HERE

We carried out a Mann-Whitney U test on the two Time 1 reading tests, with CONDITION (intervention or comparison) as the independent variable $(\mathrm{N}=116)$. We found no significant differences in either of the two tests: "translation", $\mathrm{U}=1461.5, p$ $=.17$, ns; and "idea units", $\mathrm{U}=1682.5, p=.90, \mathrm{~ns}$. Therefore, the two groups did not differ at the beginning of the study, prior to the intervention.

We then carried out a Mann-Whitney $U$ test on the two Time 2 reading tests, with CONDITION as the independent variable $(\mathrm{N}=116)$. We found significant differences in both tests: "translation", $\mathrm{U}=1041.0, p=.001 *$; and "idea units", $\mathrm{U}=$ $856.5, p=.001^{*}$. 
We were interested in exploring whether the two test types were indeed measuring different aspects of reading comprehension. We therefore carried out correlations (Spearman's rho) between them at both Time 1 and Time 2 and found low but significant correlations at Time $1\left(r=.35, p<.001^{*}\right)$, and moderate significant correlations at Time $2\left(r=.524, p<.001^{*}\right)$. Given that these interactions were suggesting that different skills were indeed being deployed in the different testtypes, we felt it justifiable to also combine and average the percentage test scores at each time point (see Table 1) in order to get an overall picture of reading comprehension performance. We carried out Kolmogorov-Smirnov and ShapiroWilcox tests of normality on the combined test scores at Time 2 and found them to be normally distributed ( $p=.200, \mathrm{~ns} ; p=.149$, ns respectively). After ensuring that the combined scores at Time 1 were significantly correlated (Pearson, 2-tailed) with scores at Time $2(r=.40, p<.01 *)$, we carried out an Analysis of Co-variance with Time 1 as the co-variate and CONDITION as the independent variable and found significant differences for CONDITION: $F(1,113)=41.7, p=.001 *$ The effect size was $\eta^{2}=.27$.

The above main effects were in favour of the intervention group as can be seen from the descriptive statistics in Table 1. In other words, the intervention group outperformed the comparison group on both measures of reading comprehension. An additional finding is that $97 \%$ of the intervention cohort attempted the Idea Units Time 2 text but only $77 \%$ of the comparison cohort made any kind of attempt at it.

\section{Research Question 2}

The second research question concerned whether learners' strategy use and general approaches to reading changed over the course of the 15 months. Following our hypotheses discussed in the introduction, we were interested in seeing patterns of change in strategy use rather than simply increases in use.

For each of the items on the strategies/approaches section of the questionnaire we carried out descriptive statistics (see Table 2) together with an independent samples t-test at Time 1. However, because of the large numbers of t-tests, we carried out a Bonferroni correction procedure on the 12 items by dividing the alpha value by the number of items and found that a true significance would have to be set at a more 
stringent $p<.005$. We therefore found significance, at Time 1 , on only one item: "invent a meaning" $(\mathrm{t}=3.27 ; \mathrm{df}=109 ; p=.001)$. The comparison cohort reported the higher usage of this item. There are no obvious reasons underlying this anomaly in the data. We should note at this point that a small number of children who were administered the questionnaire did not complete every single item on it, hence the small variation in the degrees of freedom score for some items.

We then carried out descriptive statistics (see Table 2) together with an independent samples t-test on each of the items at Time 2. This time there were four (different) items showing statistical significance $(p<.005)$. The following two items showed a significant effect in favour of the comparison group (see Figure 1):

(1) Wait for the teacher to explain the text ( $\mathrm{t}=3.69 ; \mathrm{df}=110 ; p=.001 *)$.

(2) Wait and see if the teacher says what it means ( $\mathrm{t}=2.7$; $\left.\mathrm{df}=109 ; p=003^{*}\right)$.

The following two items showed a significant effect in favour of the intervention group:

(3) Scan for words that look familiar and try to guess the meaning of the text from them. $(\mathrm{t}=3.19 ; \mathrm{df}=110 ; p=.001 *)$.

(5) Look up many words in the dictionary or glossary $(\mathrm{t}=3.3$; $\mathrm{df}=109 ; p=$ $.001 *)$.

It appears from the above results that there was some change in the reported use of strategies over the time period. Particularly, there appeared to be a shift in the intervention group towards what we would conceptualize as "text-engagement" strategies (see Brown et. al. 1996) and this, in combination with the reading test results, suggested a sign of growing learner independence and perhaps confidence. On the other hand, the comparison group continued to show signs of "teacher-reliance" strategies. We therefore combined (sum of each student's individual strategy score) what we considered to be all the "text-engagement" strategies and all those we considered to be "teacher-reliance" strategies. In the strategy descriptions in the method section the "text-engagement" strategies are numbered: 3,4,5,6,12 and the "teacher-reliance" strategies are numbered 1,2,7,8,9,10,11. Figures 1 and 2, show more clearly the shifts over the time period for both these strategy clusters for the intervention and comparison groups. 


\section{INSERT FIGURES 1 and 2 ABOUT HERE}

\section{Research Question 3}

Our third research question concerned attitudes toward reading in French. However, in order to ensure that the reading intervention had not had a detrimental effect on other aspects of their language learning, we asked the students about their feelings towards the other three language skills as well as their spelling, their French textbook and their homework tasks. Independent samples t-tests with a Bonferroni correction procedure suggested a true significance level should be set at $p<.006$.

At Time 1 there were no significant differences in attitudes towards any aspect of French learning. Fifteen months later the results from the Time 2 questionnaire revealed that attitudes had changed. Intervention students reported not only significantly more positive attitudes toward reading in French but to a further 5 out of the 8 items (see Table 3).

\section{INSERT TABLE 3 ABOUT HERE}

\section{Discussion}

The study sought to investigate the impact on young-beginner learners of a programme of strategy instruction in terms of reading comprehension success, of reading strategy use and of attitudes toward reading in French. This population had been under-represented in the relevant research literature as noted in a recent review article on L2 reading instruction (Chamot 2005).

The instruction programme was conceptualized as low input in that very little class time was allocated to the reading programme and only 7 French reading texts were introduced over and above what the students would normally have been exposed to over a period of 14 months. This was, in part, in response to the concerns expressed earlier about the time taken up by strategy instruction. The programme was also conceptualized as high-scaffolding in that, when the students engaged with the texts, they were reminded to try out strategy combinations and they received feedback about their strategy use. We would therefore exclude the confounding variable of reading 
practice effect from our results. It is highly unlikely that the intervention cohort's reading comprehension improved simply as a result of doing this small amount of extra reading. In the study we attempted to control for a number of other variables including teacher experience, course type and background of the students.

There appears to be little doubt of an overall positive impact of the strategy instruction on the intervention cohort taken as a whole. In terms of having a direct effect on reading comprehension (research question 1), the intervention cohort made significant gains both with a task requiring attention to bottom-up processes and in understanding the idea units in a text that would normally be considered much too difficult for their level. These significant gains remained in the combined test scores, suggesting a greater flexibility to adapt their reading strategy use to different text and task types. This flexibility addresses issues noted in Grabe's (2004) call for the development of the "strategic reader rather than [the teaching of] individual strategies" (p. 46). Our study, moreover, confirms Maxim's (2002) findings that, even at beginner level, students can be introduced to reading texts which are relatively challenging.

We should, however, treat the results of the "idea units" tests with some caution for two reasons. First, the mean score for the "idea units" text at Time 2 was not particularly high, even for the intervention group, although it was significantly higher than that of the comparison. We explain this partly in terms of the difficulty we had in explaining to all participants what "idea units" were, i.e. the propositions contained in the text. We could not have "trained" both groups over a long period of time in how to report idea units as this option was simply not available to us with the comparison group. Still less could we have "trained" the intervention group during the intervention as this would have clearly been invalid; the intervention had to be limited to text comprehension strategies, not test strategies. We therefore had to content ourselves with participants interpreting for themselves the level of detail the "idea units" task required. Perhaps this is the reason that none of the participants reached the total number of idea units that the researchers had gleaned from the text. However, some students in the intervention group reached as many as 22 idea units whereas the comparison group reached a maximum of 10 .

Second, a minority of intervention students clearly had little success with the idea units text despite strategy instruction, as can be seen from the range and high standard deviations. Although results show that they were more likely to attempt them 
than were the comparison cohort, these students nevertheless seemed unable to orchestrate the combinations of strategies against the task requirements. In relation to this lower achieving group among the intervention cohort, it may be possible to investigate our data further in order to see if there was a correlation between their L1 reading abilities and their ability to comprehend L2 texts. This is beyond the scope of this paper however.

We should pause here to reflect upon the type of strategy instruction programme appropriate for young-beginner readers and compare this to previous studies. As figure 1 illustrates, there was a clear shift in the reading strategies reported by the intervention cohort towards engagement with the text. It is this encouragement to engage with a difficult text (as in the Brown et. al. 1996, L1 study cited earlier) which distinguishes the kind of intervention required by this population from the adult, more sophisticated, and perhaps more motivated population in the studies by Carrell et. al. (1989) and by Talbot (1995) where the focus was on text structure. Moreover, in order for this engagement to take place it is not a question of advising or instructing students to avoid word level decoding (as might be suggested by Chamot and El-dinary's 1999 findings). Nor, conversely, is it a question of finding ways of improving lexical retrieval (see Fukkink et. al. 2005 above). Rather it is the constant juxtaposition of word/phrase recognition with prediction and search for contextual clues (see Fraser 1999), and this overlaid with the metacognitive strategy of monitoring the understanding so far against new information, that allows comprehension of a text which might otherwise provide obstacles and de-motivate the reader.

Our strategy instruction programme brought about a change in strategic behaviour via a shift towards particular combinations of strategies rather than an overall increase in individual deployment of strategies. This conceptualisation of strategy clusters which includes metacognitive evaluation, confirms the descriptive study by Macaro (2001) cited earlier. The intervention also led to a decrease in relying on the teacher, either to explain a text after the reading activity or to offer help during the activity, approaches which showed an actual increase amongst the comparison cohort as the period being investigated progressed. We see this taskrelated strategy cluster perspective on strategy instruction programmes as contributing to the similar evidence found by other researchers working in this way (Anderson, 1991; Graham, 1997) and as argued by Chamot (2005). We also consider this cluster 
perspective to be the main reason why the students did not 'misuse' their prior knowledge as previous research (e.g. McGowan and Turner 1994), at least with this age group, had found. Prior knowledge deployment was used in combination with bottom-up strategies such as "going back and checking that it made sense". In other words, we would claim that the readers who had undergone strategy instruction were now better "orchestrators" of the strategies at their disposal. We would hypothesise that this better orchestration primarily resulted from the post-task individual feedback on strategy use that the students received which fed their metacognition.

With regard to Research Question 3, the changes in attitudes of the intervention cohort are particularly interesting in the light of recent research findings, namely that by the end of Year 7, in English comprehensive schools, there is a drop in interest and motivation with regard to learning French, as reported in our introduction. The fact that the intervention cohort's attitudes to a number of aspects of learning French, improved over and above the comparison cohort is a very encouraging result. However, we would draw the reader's attentions to the limitation listed below with regard to possible researcher effect.

\section{Limitations}

Even though the sample size provides confidence in judging the trustworthiness of our results, the sample's lack of representativeness to the whole population of youngbeginner learners might be seen by some as limiting its generalizability. We would argue, however, that important insights are obtained when one tries to situate research in local contexts with context-specific research instruments and procedures. Overviews and meta-analyses of similar studies can then attempt to assess the generalizability of the findings and the weight of the evidence available. Similarly, lack of randomization of individuals to the experimental conditions might be seen as a limitation. However, once again, to improve on the design via rigorous experimental procedures would be to compromise on the natural validity that a longitudinal study involving strategy instruction requires.

Whilst our testing instruments were not standardized we would hope that the amount of piloting made them sufficiently valid. We would certainly wish to pursue a process of standardisation of the materials with a bigger sample in future. 
In classroom-based interventions such as these, there is always the possibility of some researcher effect. For ethical reasons it was important that the intervention students knew they were involved in a research project involving improving their reading comprehension. Researchers administered the pre- and post-testing and were also in class between three and four times during some of the delivery of materials that the teachers did not feel totally confident with whereas, with the comparison cohort, they were only present for the tests. However, we would argue that this researcher presence, over such a long period, could only have a minimal effect on reported strategy use. Moreover, if it were to have an effect it would most likely do so on all the strategies in the post-intervention questionnaire, rather than on strategy combinations. In other words, intervention students might try to please the researchers by ticking all the boxes in the affirmative, which was not the case. We would argue that the cluster of strategies that the students in the intervention cohort reported using was one that they adopted through the use of their own evaluation of the scaffolded strategy instruction.

Whilst we were not able to control for all variables alluded to in our introduction, we did monitor for other variables: prior knowledge of the topic of the texts - the Basra text was daily in the news at the time of administration but no students had any specific personal knowledge of the topic (e.g. parent or relative involved in the conflict); coverage of similar syllabus during the intervention period the textbook and curriculum were monitored to ensure that none of the texts favoured the intervention cohort; we matched the intervention and comparison schools for many aspects that might influence progress over the intervention months (see appendix A); we monitored the teachers' teaching approaches to ensure consistency with regard to reading skills; we triangulated the comprehension results with changes in strategic behaviour.

We would have liked to control for other factors: e.g. vocabulary knowledge, by carrying out a standardised vocabulary knowledge test but this was not possible. We would have liked to carry out a delayed post-test but, again, circumstances made this impossible.

\section{Conclusions}


Our intervention programme provides some support for the body of evidence that suggests that skill-specific strategy instruction is a good use of contact time in L2 classrooms. Particularly, it suggests that low-input but high-scaffolding over a comparatively long period of time may be an effective form of instruction for youngbeginner readers. Combinations of top-down and bottom-up strategies need to be brought to the attention of learners and they should be encouraged to use and evaluate these combinations for their effectiveness. Our results also suggest that the intervention cohort developed greater levels of autonomy in reading as a result.

Lastly, for our own context, the study provides support for a curriculum which gives greater emphasis to reading as a separate skill, which provides learners much earlier with a range of reading problems to be overcome via strategy use, and which has higher expectations of what they can achieve in the first two years of their foreign language study.

Acknowledgements

The study was funded by a Economic and Social Research Council (UK) research grant. We would like to thank Victoria Murphy for her useful comments on an earlier draft and Lars Malmberg for his advice on the statistical analysis. We are indebted to the teachers and students who took part in the project for their insights into language learning. Finally, we would like to thank the three anonymous reviewers for their very helpful suggestions in improving the quality of this report. 
Tables, figures and appendices

TABLE 1: Descriptive statistics for reading comprehension test scores at Time 1 and Time 2 expressed as percentages.

First brackets in columns represent theoretical range of raw scores.

$\mathrm{N}=116$

\begin{tabular}{|l|c|c|c|c|c|c|}
\hline & \multicolumn{5}{|c|}{ Time 1 } & \multicolumn{3}{c|}{ Time 2 } \\
\hline Condition & $\begin{array}{c}\text { Translation } \\
(0-14) \\
\text { mean (s.d.) }\end{array}$ & $\begin{array}{c}\text { Idea Units } \\
(0-20) \\
\text { mean (s.d.) }\end{array}$ & $\begin{array}{c}\text { Combined } \\
\text { scores } \\
\text { mean (s.d.) }\end{array}$ & $\begin{array}{c}\text { Translation } \\
(0-34) \\
\text { mean (s.d.) }\end{array}$ & $\begin{array}{c}\text { Idea Units } \\
(0-30) \\
\text { mean (s.d.) }\end{array}$ & $\begin{array}{c}\text { Combined } \\
\text { scores } \\
\text { mean (s.d.) }\end{array}$ \\
\hline $\begin{array}{l}\text { Intervention } \\
\text { N=62 }\end{array}$ & $76.5 \%(18.2)$ & $11.8 \%(7.3)$ & $42.9 \%(12.6)$ & $46.1 \%(15.0)$ & $21.0 \%$ (16.8) & $32.7 \%(13.8)$ \\
\hline $\begin{array}{l}\text { Comparison } \\
\text { N=54 }\end{array}$ & range: $85.7 \%$ & range: $25.0 \%$ & range: $62.5 \%$ & range: $67.6 \%$ & range: $73.3 \%$ & range: $53.1 \%$ \\
& range: $64.2 \%$ & range: $25.0 \%$ & range: $44.6 \%$ & range: $32.3 \%$ & range 33.3\% & range: $31.3 \%$ \\
\hline
\end{tabular}


TABLE 2: Descriptive statistics for strategies reported at Time 1 and Time 2

Note: 3 = Yes; 2 = Sometimes; $1=$ No.

$\mathrm{N}=116$ (Intervention $\mathrm{N}=62 ;$ Comparison $\mathrm{N}=54$ )

\begin{tabular}{|l|c|c|c|c|c|}
\hline \multicolumn{1}{|c|}{ STRATEGY } & \multicolumn{3}{|c|}{ Time 1 } & \multicolumn{2}{c|}{ Time 2 } \\
\hline & $\begin{array}{c}\text { Intervention } \\
\text { Condition } \\
\text { mean (s.d.) }\end{array}$ & $\begin{array}{c}\text { Comparison } \\
\text { Condition } \\
\text { mean (s.d.) }\end{array}$ & $\begin{array}{c}\text { Intervention } \\
\text { Condition } \\
\text { mean (s.d.) }\end{array}$ & $\begin{array}{c}\text { Comparison } \\
\text { Condition } \\
\text { mean (s.d.) }\end{array}$ \\
\hline $\begin{array}{l}\text { Wait for the teacher to explain } \\
\text { the text }\end{array}$ & $2.33 \quad(.65)$ & $2.46 \quad(.66)$ & $2.20 \quad(.57)$ & $2.59 \quad . .54)$ \\
\hline Skip the text & $1.36 \quad(.62)$ & $1.53 \quad(.61)$ & $1.50 \quad(.65)$ & $1.63 \quad(.67)$ \\
\hline Try to understand each word & $2.45 \quad(.68)$ & $2.35 \quad(.68)$ & $2.43 \quad(.67)$ & $2.12 \quad(.75)$ \\
\hline $\begin{array}{l}\text { Go back and double-check for } \\
\text { sense }\end{array}$ & $2.05 \quad(.72)$ & $2.17 \quad(.88)$ & $2.23 \quad(.68)$ & $1.96 \quad(.75)$ \\
\hline $\begin{array}{l}\text { Scan for familiar words and use } \\
\text { them to guess meaning }\end{array}$ & $2.04 \quad(.76)$ & $2.26 \quad(.71)$ & $2.62 \quad(.58)$ & $2.21 \quad(.74)$ \\
\hline $\begin{array}{l}\text { Scan for English-like words and } \\
\text { us them to guess meaning }\end{array}$ & $2.14 \quad(.81)$ & $2.24 \quad(.86)$ & $2.40 \quad(.61)$ & $2.22 \quad(.82)$ \\
\hline Guess from the pictures & $2.25 \quad(.68)$ & $2.50 \quad(.64)$ & $2.38 \quad(.71)$ & $2.42 \quad(.64)$ \\
\hline Invent a meaning & $1.20(.52)$ & $1.61 \quad(.79)$ & $1.30 \quad(.58)$ & $1.35 \quad(.60)$ \\
\hline
\end{tabular}




\begin{tabular}{|l|ll|ll|ll|ll|}
\hline Ask a friend & 2.33 & $(.63)$ & 2.28 & $(.65)$ & 2.16 & $(.63)$ & 2.33 & $(.66)$ \\
\hline Ask the teacher & 2.39 & $(.62)$ & $2.31 \quad(.74)$ & 2.17 & $(.61)$ & $2.16 \quad(.74)$ \\
\hline $\begin{array}{l}\text { Wait and see if the teacher says } \\
\text { the meaning of the text }\end{array}$ & $2.00(.75)$ & $2.11 \quad(.71)$ & 1.99 & $(.63)$ & $2.37 \quad(.69)$ \\
\hline Look up many words & $1.82 \quad(.76)$ & $1.66 \quad(.71)$ & $2.02 \quad(.64)$ & $1.58 \quad(.79)$ \\
\hline
\end{tabular}


TABLE 3: Results of attitudes to various aspects of French at Time 1 and Time 2

Note: 1 = very unhappy; 5 = very happy, $\mathrm{N}=116$

Time 1

Time 2

\begin{tabular}{clllll}
\hline AREA OF & Intervention & Comparison & Intervention & Comparison & \\
LEARNING & Condition & Condition & Condition & Condition & \\
& mean (s.d.) & mean (s.d.) & mean (s.d.) & mean (s.d.) & \\
\hline reading & $2.17(1.1)$ & $2.11(1.2)$ & $4.02(.75)$ & $3.25(.93)$ & $\mathrm{t}=4.91, \mathrm{df}=114, p=.001^{*}$ \\
speaking & $2.52(1.1)$ & $2.60(1.0)$ & $3.76(.94)$ & $3.30(1.2)$ & $\mathrm{t}=2.28, \mathrm{df}=114, p=.024$ \\
writing & $2.57(1.1)$ & $2.58(1.3)$ & $3.62(1.0)$ & $3.17(1.1)$ & $\mathrm{t}=2.30, \mathrm{df}=114, p=.023$ \\
listening & $2.52(1.2)$ & $2.62(1.2)$ & $3.79(1.1)$ & $2.98(1.0)$ & $\mathrm{t}=4.12, \mathrm{df}=114, p=.001^{*}$ \\
spelling & $2.83(1.3)$ & $2.68(1.4)$ & $3.52(1.0)$ & $2.72(1.2)$ & $\mathrm{t}=3.74, \mathrm{df}=114, p=.001^{*}$ \\
learning in & $2.60(.89)$ & $2.58(1.2)$ & $3.86(.94)$ & $3.11(1.3)$ & $\mathrm{t}=3.61, \mathrm{df}=114, p=.001^{*}$ \\
general & & & & & \\
homework & $2.81(1.3)$ & $3.47(1.4)$ & $3.10(1.3)$ & $2.38(1.2)$ & $\mathrm{t}=2.92, \mathrm{df}=114, p=.004^{*}$ \\
textbook & $2.41(.97)$ & $2.53(1.2)$ & $3.73(1.0)$ & $3.15(1.0)$ & $\mathrm{t}=3.01, \mathrm{df}=114, p=.005^{*}$
\end{tabular}




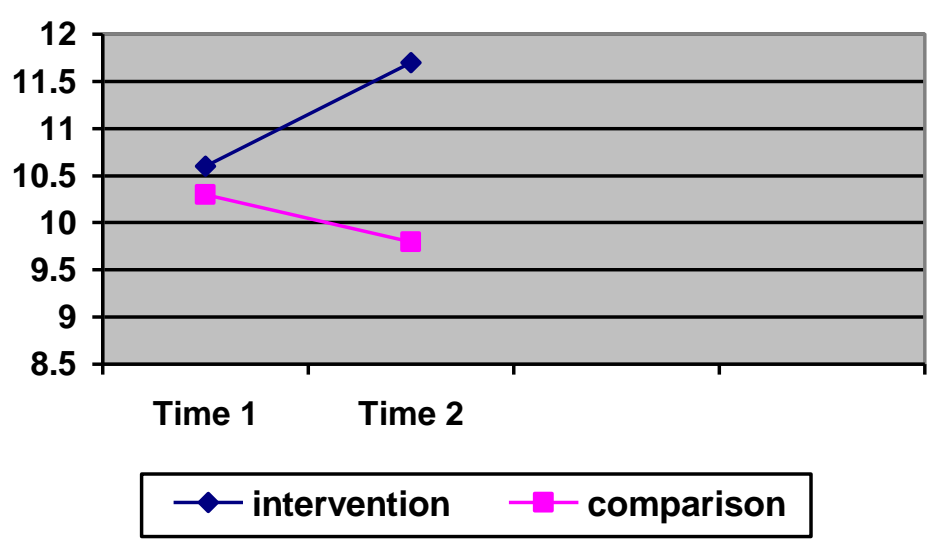

Figure 1 Combined Mean scores for "text-engagement" strategies over time

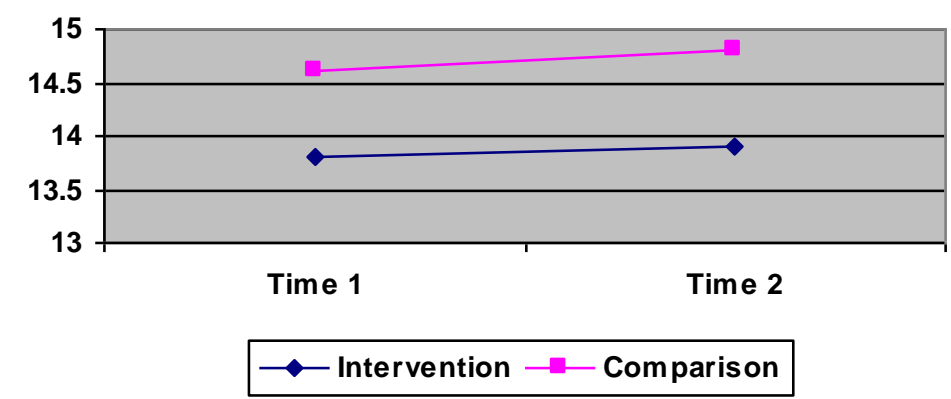

Figure 2 Combined Mean scores for "teacher-reliance" strategies over time 
Appendix A: Criteria and statistics on matched schools

\begin{tabular}{|c|c|c|c|c|c|c|c|c|}
\hline $\begin{array}{l}\text { Condi- } \\
\text { tion }\end{array}$ & $\begin{array}{l}\text { Matched } \\
\text { Schools }\end{array}$ & $\begin{array}{l}\text { Total } \\
\text { number } \\
\text { of } \\
\text { pupils } \\
\text { in the } \\
\text { school }\end{array}$ & $\begin{array}{l}\text { Number } \\
\text { of } \\
\text { pupils } \\
\text { in the } \\
\text { class }\end{array}$ & $\begin{array}{l}\% \mathrm{SEN}^{1} \\
\text { pupils in } \\
\text { the } \\
\text { school }\end{array}$ & $\begin{array}{l}\% \text { of } \\
\text { pupils } \\
\text { on roll } \\
\text { with } \\
\text { free } \\
\text { school } \\
\text { meals }\end{array}$ & $\begin{array}{l}\text { Stability } \\
\text { indicator } \\
=\% \text { of } \\
\text { pupils in } \\
\text { same } \\
\text { school } \\
\text { ages } 11- \\
16\end{array}$ & $\begin{array}{l}\% \text { of } \\
\mathrm{A}-\mathrm{C} \\
\text { grades } \\
3_{\text {in }} \\
2002\end{array}$ & $\begin{array}{l}\text { Mean CAT } \\
\text { scores of } \\
\text { the pupils in } \\
\text { the class } \\
\text { (s.d.) }\end{array}$ \\
\hline Interv. & school 3 & 1821 & 29 & $6.6 \%$ & $.03 \%$ & $97 \%$ & $51 \%$ & $99.7(7.0)$ \\
\hline Comp. & school 4 & 1498 & 28 & $7.4 \%$ & $.04 \%$ & $98 \%$ & $58 \%$ & $99.8(7.9)$ \\
\hline Interv. & school 1 & 971 & 26 & $16.4 \%$ & $11.0 \%$ & $95 \%$ & $42 \%$ & $108.0(8.4)$ \\
\hline Comp. & school 6 & 840 & 24 & $15.0 \%$ & $4.0 \%$ & $95 \%$ & $69 \%$ & 99.8 (7.9) \\
\hline Interv. & school 2 & 2138 & 29 & $11.6 \%$ & $.02 \%$ & $97 \%$ & $67 \%$ & $106.1(10.8)$ \\
\hline Comp. & school 5 & 1477 & 30 & $11.3 \%$ & $.02 \%$ & $98 \%$ & $71 \%$ & $100.6(6.1)$ \\
\hline
\end{tabular}

${ }^{1}$ pupils with special educational needs

2 a measure of socio-economic status

${ }^{3}$ English national exams in modern foreign languages taken by 16 year olds

${ }^{4}$ Cognitive Ability Tests given to all pupils upon entry to secondary school 
Appendix B: Reading Texts used in pre-tests (Time 1) and post-tests (Time 2).

\section{Translation Test at Time 1}

Translate into English. Do not worry about spelling.

Je m'appelle Marie. J'ai onze ans. J'ai les yeux bleus et les cheveux blonds.

J'ai deux demi-frères. J'habite en France et mes demi-frères habitent en Angleterre.

Dans ma trousse il y a des feutres, un stylo, des crayons, une règle et une gomme.

\section{Translation Test at Time 2}

Translate into English. Do not worry about spelling.

Je m'appelle Marie. J'ai onze ans. J'ai les yeux bleus et les cheveux blonds. J'ai deux demi-frères. J'habite en France et mes demi-frères habitent en Angleterre. L'année dernière je suis allée avec mes parents en Angleterre pour rendre visite à mes demi-frères. C'était formidable! On est allée à la plage à Brighton. Il faisait un peu froid mais j'ai nagé dans la mer avec mon demi-frère aîné Nicolas. À midi nous avons mangé du poisson et des frites comme des vrais anglais!

\section{Idea Units Test at Time 1}

Read this story. $\quad$ Hint: $\quad$ lapin $=$ rabbit

Je m'appelle Paul. Ça s'écrit comme en anglais. As-tu un animal? J'ai deux lapins, qui s'appellent Napoléon et Wellington. Mes lapins aiment jouer dans la cage où ils habitent. Aujourd'hui je regarde dans la cage et Napoléon n'est pas là! Quelle horreur!

Je cherche mon petit lapin et je ne le trouve pas. Après quelques minutes je devine qu'il est dans mon sac avec mes affaires pour l'école et voilà! C'est vrai. Il est avec mes livres, mes cahiers et ma trousse. Il est marrant!

Now make a list of 5 or more main ideas in this story. Write in English. Spellings don't count. Please write whole sentences, not just one or two words. 


\section{Idea Units Test at Time 2}

Read this text. On the next page write out all the main ideas that are in it. Write in English. Spellings don't count. Please write whole sentences, not just one or two words.

\begin{tabular}{|ll|}
\hline \multicolumn{2}{|c|}{ Vocabulaire } \\
\hline $\begin{array}{l}\text { dans la rue principale - on the main street } \\
\text { de la chance - luck }\end{array}$ & $\begin{array}{l}\text { garder - to keep } \\
\text { faire la connaissance - get to know }\end{array}$ \\
\hline
\end{tabular}

De notre correspondant à Basra en Irak

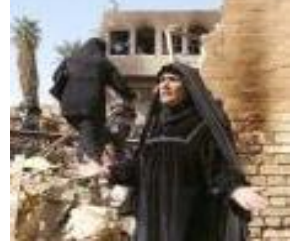

"Aujourd'hui je suis dans la rue principale de Basra. Voici un jeune homme qui s'appelle Abdul. Bonjour, Abdul."

"Bonjour."

"Abdul, vous habitez près d'ici. Il y a beaucoup

de soldats britanniques dans les rues. Est-ce qu'il y a

du calme en ce moment?"

"Oui, les soldats aident à garder le calme mais il y a toujours des bombes qui causent des explosions horribles."

"Une bombe a explosé près de votre maison?"

"Oui, une explosion effrayante! La bombe a explosé à

dix mètres de ma maison. Un mur de ma maison est complètement détruit."

"J'éspère que votre famille n'est pas blessée?"

"Non, heureusement. Au moment de l'explosion ma femme et mon père étaient dans la cuisine. Les enfants étaient à l'école et moi, j'étais au bureau."

"Alors, vous avez eu de la chance."

"Ah, oui. Il y a beaucoup à réparer dans la maison et des meubles à acheter, mais avec la famille tout va bien."

"Avez-vous fait la connaissance des soldats britanniques?"

"Oui, un peu. Ils ont joué au football avec nous. Ils sont gentils. Ils parlent un peu l'arabe. Ils ont aidés après l'explosion."

"Merci, Abdul. Je vous souhaite bonne chance pour vous et votre famille. Au revoir de Basra en Irak."
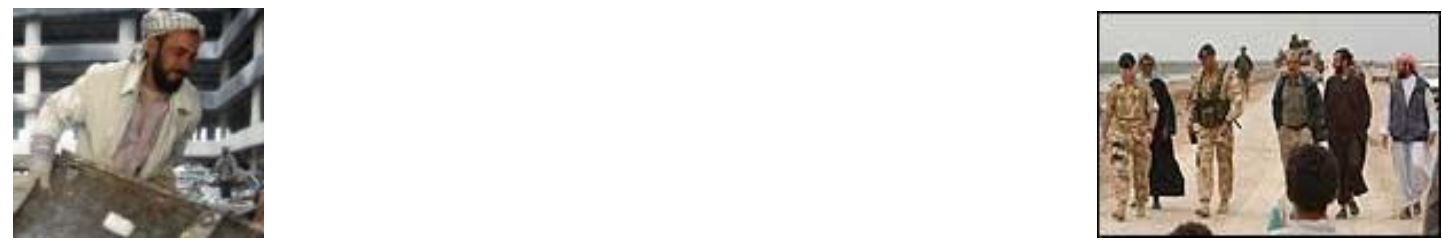
Appendix C: Questionnaire

Instructions: Read the whole page and then tick what best describes you.

\section{When you see a French text of several sentences or a paragraph, do you:}

yes $\quad \underline{\text { no }}$ sometimes

a. wait for the teacher to explain the text

b. skip it

c. try to understand each word

d. go back to a word or section and double-check that it makes sense

e. scan for words that look familiar, and try to guess the meaning of the text from them

f. scan for words that look like English and try to guess the meaning of the text from them

g. guess from the pictures what it is all about

h. invent a meaning

i. ask a friend what it means

j. ask the teacher what it means

$\mathrm{k}$. wait and see if the teacher says what it means

1. look up many words in the dictionary or glossary

m. do something else? If so, what do you do? 
Appendix D: Attitudes to French Questionnaire

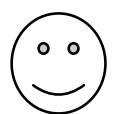

1

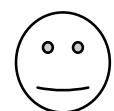

2

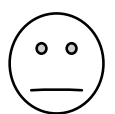

3

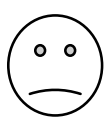

4

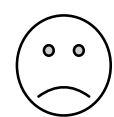

5

very happy a little happy

not happy or unhappy

Use the numbers 1 to 5 under the faces to describe, on the whole, how you feel about:

Reading French

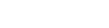

Speaking French

Spelling French

Learning French
Writing French

Listening to French

French homework

Your French textbook 
Appendix E: Examples of feedback to learners during scaffolding phase

Louise

Well done for following the instructions so carefully. It now really shows me what words you had trouble with. So you can use more strategies to help you solve the riddles of guessing. For example "le dernier film de Batman" what could "dernier" possibly mean? What would make sense? What about: "mais" in "mais je vais au cinéma.."??? Keep going. You'll get there!

Annie

Are you sure you circled all the words you didn't know? What about "on va à la piscine" do you know what "va" means here. Well done that you used a lot of the strategies on the check list. "what makes sense" is a really important strategy. You also used the "familiar bits in words", one which is really useful.

Dan

Dan you didn't circle any of the words you didn't know. If you want me to help you then you must try to follow the instructions a bit more carefully. Nice to see you using at least four strategies. Perhaps also use the "does it make sense" strategy. Also "sounding out" now that you have learnt more about the sounds of French. 
Appendix F: Example of a strategies tick list given to intervention students during instruction

Have I read the whole sentence to see if it makes sense?

Have I read ahead and then gone back to see if the meaning is more obvious?

Have I used my common sense from what I know of the situation?

Is it a word I already know?

Have I sounded out the word?

Does the word look like an English word?

Have I looked for other clues such as pictures or a title? 


\section{References}

Alderson, J.C. 2000. Assessing Reading. Cambridge: Cambridge University Press.

Anderson, N.J. 1991. Individual differences in strategy use in second language reading and testing. Modern Language Journal, 75: 460-72.

Bernhardt, E. B. 1991. A psycholinguistic perspective on second language literacy. AILA Review, 8: 31-44.

Bernhardt, E.B. 2000. Second-language reading as a case study of reading scholarship in the $20^{\text {th }}$ century. In M.L. Kamil, P.B. Mosenthal, P.D. Pearson, and R. Barr (Eds.), Handbook of Reading Research (Vol. III, pp. 791-811). Mahwah, NJ, London: Lawrence Erlbaum Associates, Publishers.

Bernhardt, E. 2005. Process and procrastination in second language reading. Annual Review of Applied Linguistics, 25: 133-150.

Block, E. 1986. The comprehension strategies of second language readers. TESOL Quarterly, 20/3: 463-494.

Brown, K. and Fletcher, A. 2002. Disaffection or disruptive engagement? A collaborative inquiry into pupils' behaviour and their perceptions of their learning in modern language lessons. Pedagogy, Culture and Society, 10/2: 169-192.

Brown, R., Pressley, M., Van Meter, P., and Schuder, T. 1996. A quasi-experimental validation of transactional strategies instruction with low-achieving second-grade readers. Journal of Educational Psychology, 88/1: 18-37.

Bügel, K. and Buunk, B. 1996. Sex differences in foreign language text comprehension: the role of interests and prior knowledge. Modern Language Journal, 80: $15-31$. 
Carrell, P.L. 1983. Some issues in studying the role of schemata, or background knowledge, in second language comprehension. Reading in a Foreign Language, 1/2: 81-92.

Carrell, P.L., Devine, J. and Eskey, D. (Eds.). 1988. Interactive Approaches to Second Language Reading. Cambridge: Cambridge University Press.

Carrell, P.L., Pharis, B.G. and Liberto, J.C. 1989. Metacognitive strategy training for ESL reading. TESOL Quarterly, 20: 463-494.

Chambers, G.N. 1993. Taking the 'de' out of demotivation. Language Learning Journal, 7: 13-16.

Chamot, A.U. 2005. Language learning strategy instruction: Current issues and research. Annual Review of Applied Linguistics, 25, 112-130.

Chamot, A., and El-Dinary, P. 1999. Children's learning strategies in language immersion classrooms. Modern Language Journal, 83/3: 319-339.

Chamot, A.U., and Keatley, C.W. ( 2003)Learning strategies of adoloescent lowliteracy Hispanic ESL students. Paper presented at the 2003 Annual Meeting of the American Educational Research Association, Chicago, IL.

Cohen, A. 1998. Strategies in Learning and Using a Second Language. London: Longman.

Coltheart, M., Patterson, K. and Marshall, J.C. (Eds.) 1980. Deep Dyslexia. London, Boston and Henley: Routledge and Kegan Paul.

Department for Education and Employment (DFEE) and Welsh Office Education Department 1995. Modern Foreign Languages in the National Curriculum. London: HMSO.

Dobson, A. 1998. MFL Inspected: Reflections on inspection findings 1996/97. 
London: CILT.

Dörnyei, Z. and Skehan. P. 2003. Individual differences in second language learning. In C. J. Doughty and M. H. Long (Eds.), The Handbook of Second Language Acquisition. pp. 589-630. Oxford: Blackwell Publishing.

Erler, L. 2002. Reading in a foreign language: Near-beginner adolescents' experiences of French in English secondary schools. Unpublished Doctoral Dissertation. University of Oxford.

Feldman, A. and Healy, A.F. 1998. Effect of first language phonological configuration on lexical acquisition in a second language. In A.F. Healy and L.E. Bourne, Jr. (Eds.), Foreign language learning: psycholinguistic studies on training and retention pp. 57-76. NJ: Lawrence Erlbaum Associates.

Flavell, J. H. 1979. Metacognition and metacognitive monitoring: A new area of cognitive-developmental inquiry. American Psychologist, 34/10: 906-911.

Fraser, C. 1999. Lexical processing strategy use and vocabulary learning through reading. Studies in Second Language Acquisition, 21: 225-241.

Fukkink, R.G., Hulstijn, J. and Simis, A. 2005. Does training in second-language word recognition skills affect reading comprehension? An experimental study. The Modern Language Journal, 89/1: 54-75.

Goodman, K.S. 1967. Reading: the psycholinguistic guessing game. Journal of the Reading Specialist, 6/1: 126-135.

Goswami, U. and Bryant, P. 1990. Phonological Skills and Learning to Read. Hove, UK: Lawrence Erlbaum Associates, Ltd.

Grabe, W. 2004. Research on teaching reading. Annual Review of Applied Linguistics, 24: 44-69. 
Grabe, W. and Stoller, F.L. 2002. Teaching and Researching Reading. Harlow, England: Longman.

Graham, S. 1997. Effective Language Learning: Positive strategies for advanced level language learning. Clevedon: Multilingual Matters Ltd.

Grenfell, M. 1992. Process reading in the communicative classroom. Language Learning Journal, 6: 48-52.

Grenfell, M. 1995. Reflections on Reading from GCSE to A Level. London: CILT.

Hammadou, J. 1991. Interrelationships among prior knowledge, inference, and language proficiency in foreign language reading. Modern Language Journal, 75: 2738.

Haynes, M. 1984. Patterns and perils of guessing in second language reading. On TESOL '83, 163-176.

Ikeda, M. and Takeuchi, O. 2000. Tasks and strategy use: empirical implications for questionnaire studies. JACET Bulletin, 31: 49-60

Jacobs, G.M., Dufon, P. and Hong, F.C. 1994. L1 and L2 vocabulary glosses in L2 reading passages: their effectiveness for increasing comprehension and vocabulary knowledge. Journal of Research in Reading, 17: 19-28.

Johnson, P. 1982. Effects on reading comprehension of building background knowledge. TESOL Quarterly, 16/4: 503-516.

Jones, B., Jones, G., Ruddock, J., Demetriou, H., and Downes, P. 2001. Boys' performance in modern foreign languages: listening to learners. London: CILT.

Kellerman, E. 1991. Compensatory strategies in second language research: a critique, a revision, and some (non-) implications for the classroom. In R. Phillipson, E. 
Kellerman, L. Selinker, M. Sharwood Smith, and M. Swain. (Eds.), Foreign/Second Language Pedagogy Research, pp.142-162. Clevedon: Multilingual Matters,.

Kitajima, R. 1997. Referential strategy training for second language reading comprehension of Japanese texts. Foreign Language Annals, 30: 84-97.

Koda, K. 2000. Crosslinguistic variations in L2 morphological awareness. Applied Psycholinguistics, 21: 297-320.

Krashen, S. 2004. The case for narrow reading. Language Magazine, 3/5: 17-19.

Kusiak, M. 2001. The effect of metacognitive strategy training on reading comprehension and metacognitive knowledge. EUROSLA Yearbook, 255-274.

La Berge, D., and Samuels, S.J. 1974. Toward a model of text comprehension and production. Cognitive Psychology, 6: 293-323.

Laufer, B. 1992. How much lexis is necessary for reading comprehension? In H. Bejoint and P. Arnaud (Eds.), Vocabulary and Applied Linguistics, pp.126-132. London: Macmillan.

LoCastro, V. 1994. Learning strategies and learning environments. TESOL Quarterly, 28/2: 409-414.

LoCastro, V. 1995. The author responds... [A response to Oxford and Green]. TESOL Quarterly, 29/1: 172-174.

Macaro, E. 2001. Learning Strategies in Second and Foreign Language Classrooms. London: Continuum.

Macaro, E. 2006. Strategies for language learning and for language use: revising the theoretical framework. Modern Language Journal. 90: 320-337. 
Maxim, H. 2002. A study into the feasibility and effects of reading extended authentic discourse in the beginning German language classroom. Modern Language Journal, 86: 20-35.

McDonough, S.H. 1995. Strategy and Skill in Learning a Foreign Language. London: Arnold.

McDonough, S.H. 1999. Learner strategies (State of the art article). Language Teaching, 32: 1-18.

McGowan, P. and Turner, M. 1994. Raising reading attainment in modern languages. In A. Swarbrick (Ed.). Teaching Modern Languages, pp. 125-137. London, New York: Routledge.

Mortimore, P., Sammons, P., Stoll, L., Lewis, D., and Ecob, R. 1988. School Matters

- the junior years. Wells, Somerset: Open Books.

Naiman, N., Fröhlich, M., Stern, H.H., and Todesco, A. 1978. The Good Language

Learner. Toronto: Ontario Institute for Studies in Education.

Nassaji, H. and Geva, E. 1999. The contribution of phonological and orthographic processing skills to adult ESL reading: evidence from native speakers of Farsi. Applied Psycholinguistics, 20: 241-267.

Nation, I. S. P. 1990. Teaching and Learning Vocabulary. Rowley, Mass.: Newbury House.

Nuffield Languages Inquiry 2002. Languages: the next generation. London: The Nuffield Foundation.

O’Malley, J.M. and Chamot, A.U. 1990. Language Strategies in Second Language Acquisition. Cambridge: Cambridge University Press.

Oxford, R. 1990. Language Learning Strategies: What every teacher should know. 
Boston: Heinle and Heinle.

Oxford, R. (Ed.). 1996. Language Learning Strategies around the World: Crosscultural Perspectives. Honolulu, HI: University of Hawai'i Second Language Teaching and Curriculum Centre.

Oxford, R., Cho, Y., Leung, S. and Kim. H-J. 2004. Effect of the presence and difficulty of task on strategy use: an exploratory study. IRAL, 42: 1-47.

Parry, K. 1993. The social construction of reading strategies: new directions for research. Journal of Research in Reading, 16/2: 148-158.

Raymond, P.M. 1993. The effects of structure strategy training on the recall of expository prose for university students reading French as a second language. The Modern Language Journal, 77: 445-458.

Rees-Miller, J. 1993. A critical appraisal of learner training: theoretical bases and teaching implications. TESOL Quarterly, 27/4: 679-689.

Rubin, J. 1975. 'What the 'Good Language Learner' can teach us'. TESOL Quarterly 9/1: 41-51.

Rumelhart, D.E. 1977. Toward an interactive model of reading. In S. Dornic (Ed.), Attention and Performance (Vol. VI, pp. 573-603). Hillsdale, NJ: Erlbaum Associates.

Samuels, S.J. and Kamil, M.L. 1988. Models of the reading process. In P.L. Carrell, J. Devine, and D. Eskey (Eds.), Interactive Approaches to Second Language Reading, pp. 22-36. Cambridge: Cambridge University Press.

Segalowitz, N., Poulsen, C. and Komeda, J. 1991. Lower level components of reading skill in higher level bilinguals: implications for reading instruction. AILA Review, 8: $15-30$. 
Stables, A. and Wikeley, F. 1999. From bad to worse? Pupils' attitudes to modern foreign languages at 14 and 15. Language Learning Journal, 20: 27-31.

Stanovich, K.E. 1980. Toward an interactive-compensatory model of individual differences in the development of reading fluency. Reading Research Quarterly, 16: $32-65$.

Steffensen, M. and Joag-Dev, C. 1984. Cultural knowledge and reading. In J.C. Alderson and A. H. Urquhart (Eds.), Reading in a Foreign Language, pp. 48-64. London and New York: Longman.

Stevick, E.W. 1990 Research on What? Some terminology. The Modern Language Journal, 74/2: 143-153.

Talbot, D.C. 1995. Metacognitive strategy training for reading: developing second language learners' awareness of expository text patterns. Unpublished Doctoral Dissertation, University of Hong Kong.

Vann, R., and Abraham, R. 1990. Strategies of unsuccessful language learners. TESOL Quarterly, 24/2: 177-198.

Wenden, A. 1995. Learner training in context: a knowledge-based approach. System, 23/2: 183-194.

Wenden, A. 1999. Metacognitive knowledge and language learning. Applied Linguistics, 19/4: 515-537.

Wenden, A. and Rubin, J. (Eds.). 1987. Learner Strategies in Language Learning. Hemel Hempstead: Prentice-Hall.

Williams, M. and Burden, R. 1999. Students' developing conceptions of themselves as language learners. The Modern Language Journal, 83/2: 193-201. 
Williams, M., Burden, R. and Lanvers, U. 2002. 'French is the language of love and stuff' - student perceptions of issues related to motivation in learning a foreign language. British Educational Research Journal, 28/4: 503-528.

\footnotetext{
${ }^{1}$ We refer to England here, rather than UK, as the Educational systems in Scotland, Northern Ireland and Wales differ from those in England.

${ }^{2}$ These are state sector, government-funded, open-entry schools for compulsory secondary education for 11-16 year olds. A "Sixth Form" for 17-18 year olds may be attached to the school.
} 